\title{
Factors That Influence Women to Be Involved in Entrepreneurship: A Case Study in Malaysia
}

\author{
N. Nadiah Hanim M. Ismail, M. Khalid M. Nasir*, Radin Siti Aishah Radin A. Rahman \\ Universiti Kebangsaan Malaysia (UKM), Selangor, Malaysia \\ Email: nadd.tm@gmail.com, ^mdkhalid@ukm.edu.my, radin@ukm.edu.my
}

How to cite this paper: Ismail, N. N. H. M., Nasir, M. K. M, \& Rahman, R. S. A. R. A. (2021). Factors that Influence Women to Be Involved in Entrepreneurship: A Case Study in Malaysia. Creative Education, 12, 837-847.

https://doi.org/10.4236/ce.2021.124060

Received: March 23, 2021

Accepted: April 22, 2021

Published: April 25, 2021

Copyright $\odot 2021$ by author(s) and Scientific Research Publishing Inc. This work is licensed under the Creative Commons Attribution International License (CC BY 4.0).

http://creativecommons.org/licenses/by/4.0/

\begin{abstract}
Women's entrepreneurship has been growing in recent years. Past studies have shown the push and pull factors influencing women entrepreneurship in general. Therefore, the aim of this study is to investigate how these factors influence women's entrepreneurship in one district in Malaysia. Interviews conducted with five successful female entrepreneurs revealed positive kappa value for push factors as compared to pull factors. The push factors found are interconnected to the necessities which include unemployment, redundancy, financial condition, lack of family financial gain, discontentment with present-day job and the needs to fulfill accommodation of work and home roles. The push factors identified are family factor, opportunity to change family lifestyle and family background. This study also focuses on the full factors which influence women to become entrepreneurs. These factors are family support, family economic status, self-independence and the desire to own a business, which contributes to the start and the sustainability of their businesses was also found in this current study.
\end{abstract}

\section{Keywords}

Entrepreneurship, Push and Pull Factors, Self-Independence, Malaysia

\section{Introduction}

Sustainable development has becoming one of the most fundamental concepts for the creation of a successful country. The Sustainable Development Goals (SDGs), or known as worldwide objectives are 17 objectives set by the United Nations. They call for activity to challenge and handle worldwide issues. The Global Goals 2020 highlighted several prominent issues such as inequality, poverty and climate change. This article focuses on the fifth objective in the SDG (Gender Equality), which is to accomplish gender equity and empower women and girls. 
On the other hand, entrepreneurship can be a "transformer" for our world thus, all the global challenges can be overcome (Apostolopoulos et al., 2018). The increase in women entrepreneurs in Malaysia indicates new progress that Malaysian women are achieving gender equality (Rani \& Hashim, 2019). Therefore, entrepreneurships in women play a big role in contributing to gender equality.

Department of Statistics Malaysia (2018) reported that the total population of Malaysia in 2018 was 29.06 million with 3.6 million Malaysians were employed as workers. From this figure, the male gender contributed for $26 \%$ of employment while the women contributed for $20.6 \%$ particularly in entrepreneurship. Thus, based on the statistics, the average equality gap between men and women stands at $69.2 \%$ and there is only $65.9 \%$ gap in economic participation and opportunity.

Department of Statistics Malaysia (2018) also reported that approximately 400,000 women in Malaysia are still unemployed. This phenomenon could trigger entrepreneurial intentions especially women in making significant relevance to develop their self, family, and country. Along with the current challenging situation, the younger generation prefers to be an entrepreneur because entrepreneurship could offer a good income.

The number of women-owned establishments in 2015 was 187,265 or 20.3\% of the total number of establishments in Malaysia. The state of Selangor recorded the highest number of establishments which is 27,111 or $14.5 \%$, followed by Kelantan (9.9\%) and Kuala Lumpur (9.4\%). According to the Department of Statistics Malaysia (2018), the value produced by women-owned establishments is $4.0 \%$ (RM39.6 billion) while the gross output value is $3.4 \%$ (RM85.0 billion). Women from Selangor were observed to own a stronghold in business in 2015. Therefore, this study intends to determine the push and pull factors which influence entrepreneurship among five women entrepreneurs in Hulu Langat, Selangor.

\section{Literature Review}

\subsection{Women Entrepreneur in Malaysia}

The economic growth of the country is influenced by the increase in women employment either formally or informally. This aids in greater rapid economic growth of the country and it helps to sustain the increment of household income, thus ensuring a fair distribution of increased income per capita. In order to achieve this aspiration, variety of programs has been executed aiming to increase the women economic status, such as encouraging women involvement in entrepreneurship. According to Kamunyu and Theuri (2017), empowering women financially could increase the overall development of the country.

As an incentive, women entrepreneurs are offered financial aid from Amanah Ikhtiar Malaysia (AIM) dan Tabung Ekonomi Kumpulan Usaha Niaga (TEKUN) to carry out their business (Alam et al., 2015). Apart from financial aids, women entrepreneurs are also supported through products, skills and entrepreneurship 
training. Encouraging women involvement in entrepreneurship becomes one of the main agendas in women economic empowerment in Malaysia (Hassan et al., 2014).

Based on the Statistics of Women Empowerment in Selected Domains in Malaysia released by the Department of Statistics Malaysia (2018), the Labour Force Participation Rate indicates significant improvement in gender equality in Malaysia, with more women taking part in economic activities. Malaysia has moved to number 70 out of 144 countries as compared to 104 out of 144 countries in the past year. In addition to increasing gender equality and economic opportunity, the government has spent 2.3 billion to encourage women's participation in entrepreneurship. This shows that the government is aware on the role of women in boosting the economy (Department of Statistics Malaysia, 2018).

Even though men entrepreneurs are the main stakeholder of entrepreneurship in Malaysia, women too are showing an increase in quantity over the years. This could be due to the reason of the need and motivation which then lead women to be an entrepreneur and contribute to the country's economic growth. Women possess unique needs and characteristics in surviving the entrepreneurial activity (Nawang et al., 2018). Based on previous findings, the needs of achievement, affiliation and power were the motivational factors which drive women to be involved in entrepreneurship. As women entrepreneurs geared up to attain goals and further progress in women entrepreneurship, the motivational factors along with the barriers faced by women entrepreneurs need to be explored further.

\subsection{Motivational Factor}

The characteristics of an entrepreneur are inclusive of being creative, innovative, courageous to grab opportunity and take risk, motivated and self-believing. In order to strive and be excellent in entrepreneurship, entrepreneurs should possess such characteristics. Nawang et al. (2018) asserted that an entrepreneur should have motivational goals as driving factor for emergence of positive attitude in a successful entrepreneurship. It is essential to have those motivational criteria as to avoid any further loss in entrepreneurship. Hence, an entrepreneur should portray and practice positive attitudes in order to become a successful entrepreneur.

One of the key elements which motivate women entrepreneurs to achieve success is emotional intelligence. Corresponding to Rhee and White, (2017), emotional intelligence is practical in women entrepreneurship and leadership quality in the $21^{\text {st }}$ century. This quality is vital for the success and ongoing growth in the particular field. Thus, in order to achieve a balanced emotional intelligence, a strong support from family is an essential key for any woman entrepreneurs. According to Abbas et al. (2016), family and social support system are a significant factor ought to bring into women-entrepreneurial success. In the 21 st century, to be a successful woman entrepreneur requires the novice to attain more flexibility and self-control towards work-home obligations as well as to attain the balanced emotional control (Agarwal \& Shah, 2014). 
Next, educational factor has become the leading element in motivating women in the entrepreneurship field. Kavitha (2014) found out that women with educational qualifications have shown more interest in becoming an entrepreneur. Education and professional experiences are the leading factor influencing woman's decision to establish a company and the growth of the firm. Additionally, Welsh et al. (2017) found out that background experience, motive of learning and issues at work could highly influence an individual to be an entrepreneur.

The government provides financial aids through loans provided by the Council of Trust or Majlis Amanah Rakyat (MARA), AIM, and Small Medium Industries Development Corporation (SMIDEC). Yogendrarajah and S.D (2015) stated that loan facilities help to create successful women entrepreneurs because the financial aids could assist in working capitals and obtaining assets for business. Along with financial aid provided for women to venture their journey in entrepreneurship, support service such as training and technical assistance are also provided. Hence, women entrepreneurs could be equipped with skills and knowledge enabling the growth in their business along with financial support, which could eventually increase the number of women entrepreneurs.

\subsection{Push and Pull Factor}

The pull factor emphasizes on the positive and desirable reasons of entrepreneurship and pulls the entrepreneurs to their choice (Džananović \& Tandir, 2020). The factor could encourage and motivate the entrepreneurs to initiate the investment. This factor influences individuals to undertake the ventures. The pull motivation is based on one's intrinsic desire to develop skills in venturing into entrepreneurship. This happens when there is an appropriate incentive to attract people towards achieving a successful entrepreneur goal. This factor is not based on the exterior force to lead a business, but it is the intrinsic factor to motivate entrepreneurs to increase productivity of a business. The pull motivation ensures the entrepreneurs to gain an ongoing energy to unlock the accomplishment awaiting ahead of them.

On the other hand, some ambition factors do not always influence individuals to undertake the activities. Sometimes, the push factors compel a person to start up a business and take on initiatives to make sure it happens. Hence the factors that put force on people to start a business are coined as push factors (Džananović \& Tandir, 2020). In other words, an individual naturally pushes away from things that cause threat to stability and comfort. The push motivation arises from human fear and individual does things to oppose the threat.

The motivational factors for women to gear up their own business begin from psychological need such as self-satisfaction (Džananović \& Tandir, 2020). According to Benzing and Chu (2009), pull factors are more prevailing than push factors. Amit and Muller (1995) opined that pull factors create more success to the entrepreneurs rather than the push motivation in term of financial. The lack 
of continuity of progress in their workplace leads women into entrepreneurship. This is further supported by Patil and Deshpande (2019) that the necessity to achieve more drives women into entrepreneurship.

The push factors for entrepreneurship among women are interconnected to the necessities. These factors include unemployment, redundancy, financial condition, lack of family financial gain, discontentment with present-day job, and the essential to fulfill accommodation of work and home roles (Amit \& Muller, 1995). Women entrepreneurs decide to be self-employed due to the pull factors in form of the thriving economy. Entrepreneurial opportunities are related to factors, such as demand for independence, necessity of challenge, reinforced financial chance, self-realization, decision to be the head of entrepreneur, flexibility of balance between family and work, accomplish personal achievement and being a role model (Amit, \& Muller, 1995). The outline of a conceptual framework is based on the push and pulls theory by Džananović and Tandir (2020) as shown in Figure 1.

\section{Methodology}

This study utilized a combination of qualitative case study and second analysis data as research design. The qualitative case study involved five women entrepreneurs operating their own businesses in the textile, food and beverages and construction industry. The researcher conducted case study as primary analysis to explore the factors which drive women to get involved in entrepreneurship. The analysis is desirable because it can make use of the collection of secondary data for a reason that was expecting by the previous researchers (Johnston, 2014).

Semi-structured interviews for five selected informants in Hulu Langat Selangor were conducted. The prerequisites for the interviewees are 1) business owners for three years and above, 2) married 3) own a business in Hulu Langat, Selangor, 4) aged between 25 to 55 and 5) women. The snowball-based sampling was used in selecting the participants. Informants who fulfilled these criteria were introduced to the researcher. Once the saturation point reached, the number of samples was determined. The thematic approach was used to analyze the interview data. Cohen's Kappa was also used to analyze the individual factors.

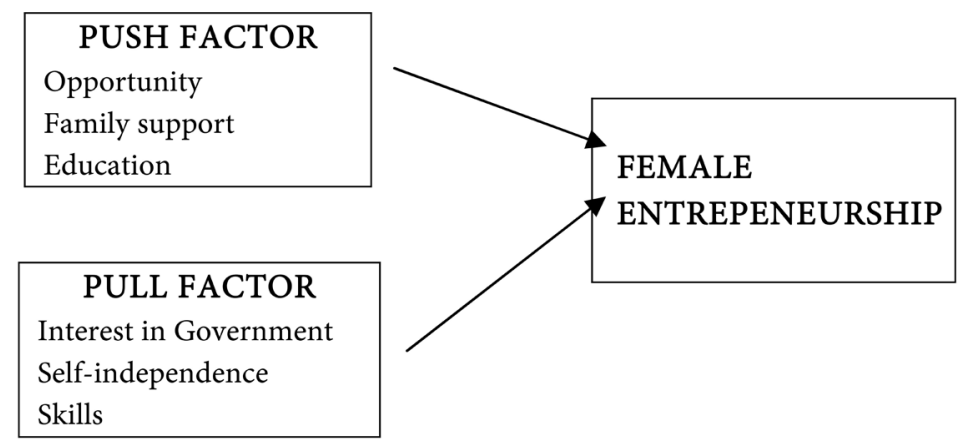

Figure 1. Push and pull factor model. 
In a research study of any manner, validity and reliability is important as it tells researchers the level to which the results indicate what they are supposed to indicate (Middleton, 2020). Reliability specifies the consistency of a tool used. Validity refers to the accuracy of data to be used (Leung, 2015). The lack of reliability and validity in a research study reduces its credibility and transparency and could create a false narrative or agenda. Cohen (1960) as cited in Mchugh (2012) suggested the Kappa result be interpreted as follows; the values $\leq 0$ as indicating no agreement and $0.01-0.20$ as none to slight, $0.21-0.40$ as fair, 041 0.60 as moderate, $0.61-0.80$ as substantial, and $0.81-1.00$ as almost perfect agreement. Among the ways to determine reliability in qualitative study is through the calculation of Cohen Kappa Index Analysis by calculating the degree of agreement between evaluator experts in qualitative study (Table 1).

Calculations:

Observed agreement, $\mathrm{Po}=5+4 / 10=0.9$

Expected agreement, $\mathrm{Pe}=[(5 / 10) \times(6 / 10)]+[4 / 10) \times(5 / 10)]=0.3+0.2=0.5$

Calculating kappa: $\mathrm{K}=(\mathrm{Po}-\mathrm{Pe})=0.9-0.5=0.4$

$$
\begin{aligned}
& (1-\mathrm{Pe})=1-0.4=0.5 \\
& 0.4 / 0.5, \mathrm{~K}=0.8
\end{aligned}
$$

The kappa value is 0.8 . This value indicates that the pull factors have positive substantial agreement from the informants. In order to increase the reliability and validity of this research, audio and video are recorded during the interview.

\section{Results and Discussion}

Since the last decade, Malaysian women have shown inclination towards entrepreneurship. The number of women entrepreneurs has substantially increased. This is a good sign that women are getting ready to be a good leader. In this section, the factors which influence women to get into entrepreneurship will be discussed. According to Nor and Ramli (2016), generating income is the main reason for women's involvement in entrepreneurship thus family, friend and previous work experiences also play significant role in initiating women's interest in entrepreneurship. Ramadani et al. (2015) also stated that women venture into entrepreneurship because they aim to elevate the household income of the family. Based on the analysis of the semi-structured interview data with five interviewees, the results show that family is one of the main factors for women to participate in the entrepreneurship activities. This finding is corroborated with previous studies that family-related factors have been found as the main factors

Table 1. Factors which influence women in Hulu Langat to be involved in entrepreneurship.

\begin{tabular}{rcccc}
\hline Raters & & Yes & No & Total \\
\hline Push Factors & Yes & 5 & 0 & 5 \\
Pull Factors & No & 1 & 4 & 5 \\
TOTAL & 6 & 4 & 10 \\
\hline
\end{tabular}


for women to be the entrepreneur. Self-interest is also found to be another factor influencing women's involvement in entrepreneurship.

\subsection{Family Support}

Previous studies discuss that family has always been the priority for women. Most of the women join entrepreneurship due to the invaluable support from the family. According to Mustapha and Subramanian (2016), family support is important and considered to be main contributor to the success of women entrepreneurs. This is supported by Zikmund et al. (2013) that family is crucial motivation for female entrepreneur.

Most of the interviewees are from business background family, as they have observed their parents managing the business and received informal training in handling the business. Thus, this helps them to value and maintain the business for long term. They also mentioned that they get to learn about profit, loss, and business-related issues since their early childhood. Hence, entrepreneurship culture has been deep-rooted in themselves as a source of income. One of the informants said:

"I am architect, but I was entrepreneur because of my father, he supports and encourage me to run restaurant in Malaysia. So, if today I am success women entrepreneur, the credit goes to my father. Other than that, my husband very supportive and he supports me to do business". (Madam A)

This shows that family support is an external factor which pushes women to be an entrepreneur with approval and support from their husband, they would feel confident to be a successful entrepreneur. In some families, father's involvement in the business is a major factor that became the impetus to the participation of individuals in business or entrepreneurship (Overbeke et al., 2015).

\subsection{Family Level of Income}

"I am from poor family, I have four girl siblings. As an elder sister, I feel I responsible to help my family and send them to higher studies. Thus, I get involved in entrepreneurship and slowly I manage the cash flow" (Miss A)

This statement shows that family level of income pushes a woman to be an entrepreneur. She wants to change her family situation and send her sisters to higher education. She is aware that entrepreneur could generate money in a short time and expand it. As Idris and Daud (2014) discussed that women entrepreneurs working in the markets found that business in the market itself could provide an opportunity for getting out of poverty. This informant is currently running textile business since 2015. Beginning from selling at car boot sale, she then expanded her business through online platform that she is now able to earn between RM4000 to RM 5000 every month. Moreover, she has her own "telekung" textile boutique in Masjid Jamek, Kuala Lumpur. The informant said:

I need to support my family and I want to change my family lifestyle. I want 
my kids to stay in the big house and living a comfortable lifestyle. (Madam B)

Many women entrepreneurs feel responsible to change their lifestyle, increase the income, and living standard (Nor \& Ramli, 2016). On the other hand, by venturing into entrepreneurship, they are able to manage household, kids and time. It makes them flexible in conducting business from home such as managing online business via e-commerce platform and media social as long as they are able to sustain their presence or engagement online (Nasir, 2020).

\subsection{Self-Independence}

Being independent and having a desire to own a business have become the pull factors and environmental factors in this research. All the informants agreed that they want to be independent and are not interested to work under any people or company. This is because they are idealistic, creative and looking for all-time freedom. This is supported by Alam et al. (2012) as they found that female entrepreneurs perceived that they do not get equal opportunities in their previous workplace, hence, they prefer to work on their own. At the same time, they feel themselves capable to earn more money instead of getting monthly salary. One of the informants said:

"I feel satisfied to work alone and earn a lot of money, I don't like to work under any company and obey to any rules, I want to be my own boss" (Miss B)

Thus, self-independence is another factor which motivated women to start a business.

\section{Conclusion}

Based on the discussion of the findings, the push factors play a significant role as compared to the pull factors in influencing women entrepreneurship. The push factors identified are family factor, opportunity to change family lifestyle and family background, while the pull factor is self-independence. These two factors play a significant role in influencing women to be an entrepreneur. Other factors such as creativity, skills and internal motivation also assist them in attracting their customers. Parents and spouse's encouragement are very important to female entrepreneurs as well. Surprisingly, women education level was not revealed as one of the main contributing factors.

This study suggests that considering the push and full factors aspect on issues related to the involvement of women entrepreneurship in Malaysia is essential. Nowadays, more women join the workforce, become business owners and entrepreneurs. This indicates that women likewise play a significant role in society and are the support to the community. Their involvement in entrepreneur would strengthen Malaysia's economy. There is an urgent need of collaboration and clear policies from government or non-governmental organization (NGO) to assess the issues faced by women entrepreneurs in regards to strengthening women entrepreneurship development and assisting them in achieving their full entrepreneurial potential in Malaysia. 


\section{Acknowledgements}

This research was funded by the Faculty of Education's research grant, Universiti Kebangsaan Malaysia (UKM) under the project code GG-019-021 and DCP-017-020/3. The researchers would like to thank Allah S.W.T for his blessing. The authors would also express their gratitude to everyone who directly or directly contributed to the completion of this study and supported this research, specifically the supervisors in UKM, the study's participants and others who contributed to this study.

\section{Conflicts of Interest}

The authors declare no conflicts of interest regarding the publication of this paper.

\section{References}

Abbas, T., Abrar, M., Saleem, R., \& Iqbal, A. (2016). What Leads to Success for Women Entrepreneurs? An Empirical Study of Southern Punjab in Pakistan. Academic Research International, 7, 120-130.

Agarwal, R., \& Shah, S. K. (2014). Information Wellsprings of Business Company: Firm Improvement by Using Scholarly, Patron and Worker Trend-Setters. Research Policy, 43, 1109-1133. https://doi.org/10.1016/j.respol.2014.04.012

Alam, M. M., Hassan, S., \& Said, J. (2015). Performance of Islamic Microcredit in Perspective of Maqasid Al-Shariah. Humanomics, 31, 374-384. https://doi.org/10.1108/H-12-2014-0072

Alam, S. S., \& Senik, Z. C., \& Jani, F. M. (2012). An Exploratory Study of Women Entrepreneurs in Malaysia: Motivation and Problems. Journal of Management Research, 4, 282-297. https://doi.org/10.5296/jmr.v4i4.2377

Amit, R., \& Muller, E. (1995). "Push" and "Pull” Entrepreneurship. Journal of Small Business \& Entrepreneurship, 12, 64-80. https://doi.org/10.1080/08276331.1995.10600505

Apostolopoulos, N., Al-Dajani, H., Holt, D., Jones, P., \& Newbery, R. (2018). Entrepreneurship and the Sustainable Development Goals. Contemporary Issues in Entrepreneurship Research, 8, 1-7. https://doi.org/10.1108/S2040-724620180000008005

Benzing, C., \& Chu, H. M. (2009). A Comparison of the Motivations of Small Business Owners in Africa. Journal of Small Business and Enterprise Development, 16, 60-77. https://doi.org/10.1108/14626000910932881

Department of Statistics Malaysia (2018). Women Empowerment in Selected Domains, 2020. https://www.dosm.gov.my/v1/index.php?r=column/pdfPrev\&id=QlliTUxPQnhrR2tVa \%202kyOFpkWmhaZz09\%20D\%C5\%BEananovi\%C4\%87,\%20D

Džananović, D., \& Tandir, N. (2020). Motivational and Limiting Factors for Female Entrepreneurship. Open Journal for Research in Economics, 3, 1-8. https://doi.org/10.32591/coas.ojre.0301.01001d

Hassan, F., Ramli, A., \& Desa, M. N. (2014). Rural Women Entrepreneurs in Malaysia: What Drives Their Success? International Journal of Business and Management, 9, 10-21. https://doi.org/10.5539/ijbm.v9n4p10

Idris, N. A., \& Daud, N. A. (2014). Aktiviti hilirin di kawasan FELDA: Analisis faktor pendorong penglibatan wanita dalam aktiviti perniagaan. Prosiding PERKEM ke-9, 
467-476.

Johnston, M. (2014). Secondary Data Analysis: A Method of Which the Time Has Come. Qualitative and Quantitative Methods in Libraries, 3, 619-626.

https://www.researchgate.net/publication/294718657 Secondary Data Analysis A M ethod of Which the Time has Come

Kamunyu, C. W., \& Theuri, F. S. (2017). Factors Affecting Growth of Women Owned Small and Medium Enterprises in Kenya: A Survey of Women-Led SMEs in South Coast Ukunda. International Journal of Social and Development Concerns, 19, 60-66.

Kavitha, G. (2014). Attitude of Youth towards Entrepreneurship-An Exploratory Study among the College Students in Coimbatore District. Zenith International Journal of Multidisciplinary Research, 4, 170-180.

http://zenithresearch.org.in/images/stories/pdf/2014/sep/ZIJMR/18 ZIJMR VOL4 ISS UE9 SEPT2014.pdf

Leung, L. (2015). Validity, Reliability, and Generalizability in Qualitative Research. Journal of Family Medicine and Primary Care, 4, 324-327.

https://doi.org/10.4103/2249-4863.161306

McHugh, M. L. (2012). Interrater Reliability: The Kappa Statistic. Biochemia Medica, 22, 276-282. https://hrcak.srce.hr/89395 https://doi.org/10.11613/BM.2012.031

Middleton, F. (2020). Reliability vs Validity: What's the Difference? https://www.scribbr.com/methodology/reliability-vs-validity

Mustapha, M., \& Subramanian, P. (2016). Challenges and Success Factors of Female Entrepreneurs: Evidence from a Developing Country. International Review of Management and Marketing, 6, 224-231.

Nasir, M. K. M. (2020). The Influence of Social Presence on Students' Satisfaction toward Online Course. Open Praxis, 12, 485-493. https://doi.org/10.5944/openpraxis.12.4.1141

Nawang, W. M. Z. W., Mamat, I., \& Sa'at, N. H. (2018). The Relationship between Predictor Factors and Career Inclination of Entrepreneurship among Program Tunas Niaga Members. Akademika, 88, 19-31.

Nor, Z. M., \& Ramli, Z. (2016). A Glimpse at Women Entrepreneurs in Penang. Akademika, 86, 79-86. https://doi.org/10.17576/akad-2016-8602-06

Overbeke, K. K., Bilimoria, D., \& Somers, T. (2015). Shared Vision between Fathers and Daughters in Family Businesses: The Determining Factor That Transforms Daughters into Successors. Frontiers in Psychology, 6, 625. https://doi.org/10.3389/fpsyg.2015.00625

Patil, P., \& Deshpande, Y. (2019). Why Women Enter into Entrepreneurship? An Exploratory Study. Journal of Organisational Studies and Innovation, 6, 30-40.

https://www.researchgate.net/publication/334389192 Why Women Enter Into Entre preneurship An Exploratory Study\#fullTextFileContent

Ramadani, V., Hisrich, R. D., \& Gerguri, S. (2015). Female Entrepreneurs in Transition Economies: Insights from Albania, Macedonia and Kosovo. World Review and Entrepreneurship, Management and Sustainable Development, 11, 391-413. https://doi.org/10.1504/WREMSD.2015.072066

Rani S. H. A., \& Hashim, N. (2019). The Impact of Networking among Women Entrepreneurial Success. https://ir.uitm.edu.my/id/eprint/35346

Rhee and White (2017). The Relationship between the Emotional Intelligence of Entrepreneurs and the New Venture Creation: The Role of Age, Gender and Motive. Arab Economic and Business Journal, 12, 99-108. https://doi.org/10.1016/j.aebj.2017.10.002

Welsh, D. H. B., Kaciak, E., \& Shamah, R. (2017). Determinants of Women Entrepre- 
neurs' Firm Performance in a Hostile Environment. Journal of Business Research, 88, 481-491. https://doi.org/10.1016/j.jbusres.2017.12.015

Yogendrarajah, R., \& S.D, S. (2015). Micro Credit Is a Tool for Women Entrepreneurship Development. Journal of Mathematics and System Science, 5, 385-390. https://doi.org/10.17265/2159-5291/2015.09.005

Zikmund, W. G., Babin, B. J., Carr, J. C., \& Griffin, M. (2013). Business Research Methods. Boston, MA: Cengage Learning. 